\title{
Extraterritorial obligations in the inter-American human rights system
}

\author{
Clara Burbano-Herrera and Yves Haeck
}

\section{Introduction}

The conduct of states may affect the human rights of individuals located outside their borders. In the inter-American human rights system (IAHRS), the scope of extraterritorial obligations is linked to the universality principle and the jurisdiction clause. States are internationally responsible for not only human rights violations that were attributed to them within their own territory, but also for actions or omissions perpetrated outside their territory but within their jurisdiction. This chapter explores the criteria developed by the Inter-American Commission on Human Rights (IACmHR; Commission) and the Inter-American Court of Human Rights (IACtHR; Court) to establish the international responsibility of states in the framework of extraterritorial obligations in specific cases and identifies the types of situations in which extraterritorial responsibility has been established. First, following some background on the IAHRS, the provisions related to extraterritorial jurisdiction and obligations will be dealt with. Second, the Commission's and Court's case-law under the Declaration and/or the Convention will be examined. We will end with some conclusions.

\section{Brief background to the inter-American system}

The IAHRS has three protection levels: states which have not ratified the ACHR have obligations under the Declaration and are supervised by the Commission; states having ratified the ACHR are obligated under it and are supervised by the Commission; states having ratified the Convention and having accepted the IACtHR's jurisdictional competence are obligated under the Convention and are supervised by the Commission and Court.

The Charter of the Organization of American States (OAS), the American Convention and the IACmHR Statute provide that the Commission is an OAS organ created to promote the observance and defense of human rights. The Commission interprets not only the American Convention (1969), but also the American Declaration (1948). The Declaration is not a treaty, but it imposes indirectly obligations upon all 35 states, through their OAS membership. The 
IACmHR was created through a political decision of the Ministers of Foreign Affairs of the American states (1959). The Commission started to document violations and promote human rights applying the Declaration, being the only existing regional instrument at that time. Subsequently, the Commission was granted competence to examine individual petitions alleging human rights violations (1965). Thus, the Commission, when examining the complaints, also started to apply the jurisdiction clause to all OAS states (see infra). The Convention, which entered into force in 1978, has not been ratified by all OAS states (e.g., the US; Canada; some Caribbean states), while others have even denounced it (e.g., Trinidad/Tobago). The Convention created the IACtHR, which started to work in 1979 but only began to exercise its judicial competences in earnest in 1988.

In general terms, the international obligations of the states to the IAHRS are contemplated in Articles 1 and 2 ACHR, and can be classified into: (i) Obligation to respect human rights; (ii) Obligation to guarantee human rights; (iii) Obligation to adapt the domestic law. These obligations are sufficient to structure the responsibility of the states. Besides, the rights under the Declaration are also a source of similar international obligations for the OAS states.

In the Americas, the supervisory bodies connect the extraterritorial application of human rights with the recognition of the principle of universality and the so-called jurisdiction clause. The universality principle affirms that all people must enjoy all human rights anywhere in the world, while the jurisdiction clause indicates under which circumstance states are obligated beyond their territory. While the Declaration does not explicitly contain a jurisdiction clause, the American Convention does.

\section{Extraterritorial obligations in the American Declaration}

The Declaration does not include an explicit mention of limitation of its territorial scope, nor any other explicit jurisdiction clause. Curiously, the Declaration drafts prepared by the Inter-American Juridical Committee did contain a jurisdiction clause. Article XVIII 1945 Draft linked it to the principle of equality. The 1947 final Draft Declaration of the Committee submitted to the Bogota Conference still contained the reference to jurisdiction in the equality clause (Art. XVIII(2)). Eventually, the reference to jurisdiction was deleted in the renumbered Article II:

All persons are equal before the law and have the rights and duties established in this

Declaration, without distinction as to race, sex, language, creed or any other factor.

The Working Group Human Rights chose not to include the duties (of the state), concluding that to do so would exceed its mandate and that it would detract from the forcefulness and clarity of the Declaration (Report Rapporteur, in Buergenthal and Norris 1982-1983, p. 16).

The general human rights obligations on OAS states under the Declaration and the absence of a reference to jurisdiction have not precluded the IACmHR from using the provision as the basis for assessing the extraterritorial responsibility of states under the Declaration. In the IAHRS, most cases concerning extraterritorial application have been decided by the Commission under the Declaration, applying the universality principle together with the (implicit) jurisdiction clause. 


\section{Extraterritorial obligations in the American Convention}

The American Convention does not contain a provision on extraterritorial human rights obligations, but contains an explicit jurisdiction clause, which is almost identical to that in the European Convention on Human Rights. Article 1(1) says:

The states Parties to this Convention undertake to respect the rights and freedoms recognized herein and to ensure to all persons subject to their jurisdiction the free and full exercise of those rights and freedoms, without any discrimination for reasons of race, color, sex, language, religion, political or other opinion, national or social origin, economic status, birth, or any other social condition (emphasis added).

An IACmHR draft, adopted by the OAS Council (12 October 1968), was based on three drafts. The subsequent draft Convention adopted by the OAS Council in 1968 referred to 'all persons within their territory and subject to their jurisdiction' and its similarity to Article 2(1) ICCPR was mentioned in the IACmHR's annotations on the draft Convention. The IACmHR and the US agreed with the text and did not propose any amendments, and the IACmHR did not even comment on the wording of the phrase concerned.

During the San Jose Conference, the main change proposed by a Working Group of Committee I was the deletion of the words 'within their territory'. Panama wanted to delete the phrase in order to protect the human rights of residents in the Panama Canal Zone which was subject to US jurisdiction but was not US territory, and the US apparently did not oppose.

The draft Working Group text of Article 1(1) was subsequently unanimously adopted by the Committee.

The interpretation of the jurisdiction clause in the Convention and the implicit clause in the Declaration, as developed by the Commission and Court through country reports, the individual and interstate petition system procedure, precautionary measures and an advisory opinion, will now be examined. As will be shown, a broad range of rights and freedoms have been given extraterritorial application by the IACmHR (Cassel 2004, p. 176), while the IACtHR has until now only done this in a single situation.

\section{Extraterritorial obligations under the American Declaration and Convention in practice}

The Commission has adopted the same interpretation regarding extraterritorial obligations and therefore extraterritorial responsibility with respect to states that have ratified the Convention and those which have not yet done so. In other words, these cases are not decided differently from the ones submitted under the American Declaration (Cerna 2004). Moreover, the Commission has held that in order to establish state responsibility for extraterritorial human rights violations, it is necessary to prove the exercise of state jurisdiction and therefore there needs to be 'authority and effective control'. Overall, the essential tool in determining jurisdiction and establishing the responsibility of a state for acts committed by its agents abroad, is the 'exercise of authority over persons' by state agents, without necessarily requiring the existence of a formal, structured and prolonged legal relation in terms of time. The Commission has indicated that a state's international responsibility may refer to extraterritorial actions when the person is present in the territory of a state but is subject to the control of another state, generally through 
the actions of that state's agents abroad. It has therefore recognized the exercise of extraterritorial jurisdiction in cases relating to military interventions, operations in international airspace and on the territory of third states, as well as in detention facilities outside a state's territory.

In Saldaño, the first petition decided by the Commission on extraterritorial responsibility in the framework of the American Convention, an Argentinian sentenced to death in the US, argued that during the trial certain rights under the Declaration (rights to life; liberty and personal security; fair trial; petition; due process of law) and the Convention had been violated. Under the latter, the petitioner alleged that Argentina had an obligation to present an interstate complaint against the US, and the failure of doing this rendered it responsible for human rights violations (rights to life; fair trial; judicial protection). The Commission held:

(...) a state party to the American Convention may be responsible under certain circumstances for the acts and omissions of its agents which produce effects or are undertaken outside that state's own territory.

(IACmHR 1999a, para. 17)

Furthermore, (...) the understanding of jurisdiction and therefore responsibility for non-compliance with international obligations (.) is a notion linked to authority and effective control, and not merely to territorial boundaries (emphasis added).

(Ibid, para. 19)

In casu, there was no proof that Argentina had exercised authority or control over Saldaño under Article 1(1) ACHR, and he was thus not within Argentinian jurisdiction prior/subsequent to his arrest in the US, or that Argentina had exercised authority or control over the local US officials involved in the subsequent criminal proceedings, and the mere bond of being Argentinian was not sufficient either (ibid, paras. 21-23). Argentina also had no Conventional obligation to lodge an interstate complaint against the US (ibid, paras. 1-3 and 32-34).

\section{Extrajudicial killings and harassment by state agents}

The Commission has implicitly established the extraterritorial scope of the Declaration and the responsibility of OAS states for extrajudicial killings and harassment by state agents in a Country Report on Chile (1985) and another one on Suriname (1985), when fulfilling its general monitoring function (Cerqueira 2015, p. 19).

In the Chile Report, the Commission referred to the murder on Chileans outside Chile, more specifically two former high-ranking officials of the Allende government, namely, the former Minister of state and Ambassador Orlando Letelier, and the former commander-in-chief of the army, general Carlos Prats (IACmHR 1985a, paras. 80-91), respectively, in Washington DC and Buenos Aires, by Chilean secret agents (right to life). The Commission explicitly held that the seriousness of these events ' (...) lies in the method used in the respective crimes and in the fact that they took place beyond the frontiers of Chile' (IACmHR 1985a, para. 80).

Similarly, in its Suriname Report, the Commission referred to the attacks on and harassment of Surinamese in the Netherlands by Surinamese agents. The Commission took special note of ' $(. .$.$) the numerous and serious allegations made by Surinamese citizens both in the Neth-$ erlands and Suriname that the Government of Suriname, through its Consulate at the Hague and through its agents in the emigrant community, [had] threatened members of the refugee 
community with reprisals against their relatives remaining in the country if their anti-government activities didn't cease'. The Surinamese citizens were prevented from obtaining passports and returning home (right to a passport) if they were considered to be opponents (IACmHR 1985b, Chapter V, Introductory Section).

\section{Use of force by state agents during military operation/intervention}

The extraterritorial scope and the responsibility of OAS states under the Declaration was first implicitly and later explicitly recognized by the Commission in cases concerning US military interventions in Grenada/Panama, as well as Ecuadorian and Colombian military operations on each other's territory.

Disabled Peoples' International (DPI), the first petition submitted against a state in the Americas alleging extraterritorial responsibility under the Declaration, was filed following the US intervention in Grenada in 1983 (IACmHR 1987) and more specifically the bombing of a psychiatric institution, killing 16 and injuring 6 persons (rights to life; preservation of health and well-being). The applicants held that, since Article 112 OAS Charter provides that the Commission's main function was to promote the observance and protection of human rights, the complaint was within the Commission's competence.

The Commission declared the petition admissible in 1986, indicating that it had jurisdiction to examine the allegations, without explicitly touching upon the extraterritorial jurisdiction issue, as none of the parties had alleged anything in that regard (IACmHR 1987).

The US position was that the Commission lacked competence because the facts concerned a country with an internal armed conflict, and the Commission is only allowed to apply the Declaration but not the Fourth Geneva Convention which regulates actions within the political context concerned - a position maintained ever since (infra). Eventually, the merits of the case were not assessed because a friendly settlement was reached (IACmHR 1996, Background para. IV).

Coard was also related to US military actions during its intervention in Grenada, but this time the petition was submitted by 17 Grenadian petitioners who had been actively involved in deposing the government (IACmHR 1999b). In October 1983, rival members of the prime minister's party murdered the Grenadian prime minister and some government members and established a Revolutionary Military Council (RMC). Some days later, the US and Caribbean armed forces invaded Grenada, deposing the RMC. During the US-led operation, the petitioners had allegedly been unlawfully detained by US forces, held incommunicado for many days and ill-treated, and they contended that the US corrupted the Grenadian judicial system thereby depriving them of their right to a fair trial (ibid, paras. 2-4 and 17-20). In 1994, the Commission admitted the case (IACmHR Coard 1994, unpublished).

In order to determine US jurisdiction, the Commission considered the 'effective control and authority over the presumed victims' ('personal jurisdiction model'), thereby reading into the Declaration a state jurisdiction requirement which is actually not included into the text itself. Geographic location and territorial jurisdiction did not play a (decisive) role. Indeed, while the petitioners were detained on US military ships, which could basically be seen as bringing the persons concerned under US jurisdiction, the Commission did not say a word on this, nor did it hold that from the moment that the petitioners had been detained, US military had already 
gained full control over Grenada. As a reason for its standpoint, it held that 'individual rights inhere simply by virtue of a person's humanity'. More specifically, the Commission said:

While the extraterritorial application of the American Declaration has not been placed at issue by the parties, (...) jurisdiction over acts with an extraterritorial locus will not only be consistent with, but required by the norms which pertain. The fundamental rights of the individual are proclaimed in the Americas on the basis of the principles of equality and non-discrimination (...). Given that individual rights inhere simply by virtue of a person's humanity, each American state is obliged to uphold the protected rights of any person subject to its jurisdiction. While this most commonly refers to persons within a state's territory, it may, under given circumstances, refer to conduct with an extraterritorial locus where the person concerned is present in the territory of one state, but subject to the control of another state usually through the acts of the latter's agents abroad. (...) the inquiry turns not on the presumed victim's nationality or presence within a particular geographic area, but on whether, under the specific circumstances, the state observed the rights of a person subject to its authority and control (emphasis added).

(IACmHR 1999b, para. 37)

Given that the victims had been subjected to the extraterritorial authority and control of the US authorities, the US was found in violation of the Declaration (rights to life; protection of juridical personality; protection from arbitrary arrest), in view of the victims '(being) held in the custody $(. .$.$) for approximately nine to twelve days, including six to nine days after the effective$ cessation of fighting', while 'the petitioners were not afforded access to a review of the legality of their detention with the least possible delay' (ibid, paras. 60-61). Furthermore, the Commission reiterated the legal basis of its competence deriving from the OAS Charter, its Statute and Regulations (ibid 1999, paras. 9 and 36). The US once again contested the admissibility of the case asserting the Commission's lack of competence to examine the legal validity of its military actions in Grenada as this fell beyond the scope of its mandate, particularly with regard to a non-state party to the Convention. The Commission (IACmHR Coard 1994) dismissed the US objections related to the alleged lack of competence to examine the US actions and reiterated that the Declaration 'is a source of international obligation for member states not party to the American Convention', and that its Statute authorizes it to examine complaints under the Declaration, an approach which it has maintained ever since.

In a subsequent case decided under the Convention related to the alleged extra-judicial execution of an Ecuadorian by the Colombian army on Ecuadorian territory (IACmHR 2010), the Commission explicitly stated that

(...) $[\mathrm{u}]$ nder Inter-American human rights law, each American state is obligated (...) to respect the rights of all persons within its territory and of those present in the territory of another state but subject to the control of its agents.

(Ibid, para. 91, referring to IACmHR 1999c; further: IACmHR 2011b, para. 23; IACmHR 1993)

Rejecting the Colombian argument that the alleged victim was not subject to Colombian jurisdiction, the Commission held that according to the Vienna Convention the term jurisdiction in Article 1(1) must be interpreted in good faith and be understood and applied in its ordinary meaning as a term of international law, because it is clear that the parties did not intend otherwise (IACmHR 2010, para. 88; Vienna Convention on the Law of Treaties, Art. 31(1) and (3) (c)). Also, the Convention's drafting history did not indicate that the parties intended to give a 
special meaning to 'jurisdiction' (ibid, para. 89). Moreover, they omitted the reference to 'territory', thereby widening the scope of protection to the extent that the states not only may be held internationally responsible for the acts and omissions imputable to them within their territory, but also for those acts and omissions committed wherever they exercise jurisdiction (ibid, para. 90).

In its case law, the Commission stresses that it had to be established whether there was a causal link between the extraterritorial conduct of a state through the actions or omissions of its agents and/or persons who have acted under its orders or acquiescence and the alleged violation of the rights and freedoms (rights to life; humane treatment; fair trial; due process) of an individual (IACmHR 2010, para. 99; also: IACmHR 2011b; IACmHR 2018).

\section{Downing of civilian airplanes by state agents}

In Armando Alejandre Jr, which involved the 1996 downing in international airspace of two unarmed civilian light airplanes belonging to the organization 'Brothers to the Rescue' by the Cuban military resulting in the immediate death of four persons on board, the Commission reaffirmed - implicitly - that it was clearly competent with respect to the alleged human rights violations committed by Cuba despite the fact that Cuba was not a state party to the American Convention (IACmHR 1999c, paras. 1 and 23).

Following its jurisprudence in the US-related cases, the Commission held that although a state's jurisdiction ratione loci is primarily territorial, exceptions exist in limited circumstances based on the principle of universality and when the victims were under the control or authority of the foreign agents. The Commission held more specifically:

(...) the Commission is competent to consider reports alleging that agents of an OAS member state have violated human rights protected in the inter-American system, even when the events take place outside the territory of that state. (...) Because individual rights are inherent to the human being, all the American states are obligated to respect the protected rights of any person subject to their jurisdiction. Although this usually refers to persons who are within the territory of a state, in certain instances it can refer to extraterritorial actions, when the person is present in the territory of a state but subject to the control of another state, generally through the actions of that state's agents abroad. In principle, the investigation refers not to the nationality of the alleged victim or his presence in a particular geographic area, but to whether, in those specific circumstances, the state observed the rights of a person subject to its authority and control (emphasis added).

(Ibid, para. 23)

The Commission considered that the victims died as a consequence of direct actions taken by Cuban state agents in international airspace (ibid, para. 25). It was clear that the power and control exercised by the state agents had provoked jurisdiction. The Commission said:

(...) The fact that the events took place outside Cuban jurisdiction does not limit the Commission's competence ratione loci, because, as previously stated, when agents of a state, whether military or civilian, exercise power and authority over persons outside national territory, the state's obligation to respect human rights continues, in this case the rights enshrined in the American Declaration. The Commission finds conclusive evidence that agents of the Cuban state, 
although outside their territory, placed the civilian pilots of the 'Brothers to the Rescue' organization under their authority (emphasis added).

(Ibid, para. 25)

The Commission declared Cuba responsible for violating the Declaration with respect to the four persons who had died as a result of the direct actions of its agents while flying through international airspace (rights to life; freedom of movement).

\section{Use of force by state agents when arresting and/or abducting a person}

The Alikhani case, which concerns a transnational abduction, allowed the Commission to assert that such abduction cases also amount to the exercise of extraterritorial jurisdiction by an OAS state.

The petitioner, a dual citizen of Iran and Cyprus, was lured to the United States by US agents from an airport in the Bahamas on the false premise that he would be flying to another Bahamian island for a business meeting and some fishing. After the plane had left the runway, the petitioner was arrested for violating US sanctions against Libya. The applicant held that the Bahamas had not authorized his arrest on its territory. In its admissibility report, the Commission asserted its competence ratione loci, given that:

The petition indicates that Mr. Alikhani was under the jurisdiction of the United States at the time of his arrest, detention and subsequent criminal proceedings.

(IACmHR 2005, para. 42)

While the case has been declared admissible with regard to the rights to life, residence and movement, right to petition, protection from arbitrary arrest and due process of law, the case has not yet been decided on the merits.

\section{Use of force by state agents when detaining persons on board of naval vessels on the high seas, sending them to an overseas detention centre or returning them to country of origin}

In Haitian Centre for Human Rights, the exercise of extraterritorial jurisdiction over persons detained and/or deported by a state on the high seas was implicitly but clearly established. In establishing the jurisdiction of the US, the Commission used the control over person's test.

The petition alleged that Haitians fleeing their country had been stopped at sea (interdicted), taken on board US vessels and returned to Haiti or Guantanamo Bay, thereby preventing them from landing on US shores and acquiring certain procedural rights to apply for asylum and thus without affording them an opportunity to establish whether they qualified as refugee (IACmHR 1997).

The Commission found that the US act of interdicting Haitians on the high seas and placing them in vessels under its jurisdiction, sending some of them to Guantanamo and returning others to Haiti and leaving them exposed to acts of brutality by the Haitian military and its supporters, amounted to a violation of the right to security of the Haitians, as well as the rights to life; liberty; equality before the law; fair trial; and asylum under the Declaration (IACmHR 1997, paras. 171 and 183).

Subsequently, the US responded by letter, stating that ' $(.$.$) the Commission's analysis is$ legally flawed. For example, it was error to hold that the 1967 Protocol to the UN Convention on the Status of Refugees applies to Haitian migrants interdicted on the high seas. It was also 
error to interpret the non-refoulement obligation to require high seas interdicts to receive the same hearing on their asylum claims as they would receive if they were present within the territory of the interdicting state (...)' (ibid, para. 82). The US did not recognize the competence of the Commission and its interpretation of the Declaration about US extraterritorial acts occurring outside its territory but within its jurisdiction on the high seas.

\section{Use of force by state agents when detaining persons in overseas detention centres}

The indefinite detention of persons outside the territory, in overseas detentions centres by the US within the inter-American espace juridique (post-9/11 detainees in Guantanamo Bay) but also beyond the inter-American espace juridique (Bagram airbase, Diego Garcia, etc.) amounts to an exercise of extraterritorial detention.

In the Guantanamo detainees case, the Commission adopted precautionary measures in 2002 in favour of detainees held by the US at Guantanamo Bay, Cuba (IACmHR 2002, p. 16; Burbano Herrera and Viljoen 2015, p. 182), thereby implying that they were under US jurisdiction. Approximately 254 detainees were at that moment being held in Guantanamo (IACmHR 2011a (extension)) following their capture in Afghanistan. The detainees were allegedly at risk of irreparable harm because the US refused to treat them as prisoners of war until a competent tribunal determined otherwise in accordance with the Third Geneva Convention (IACmHR 2002). According to the petitioners, the detainees had been held arbitrarily, incommunicado and for a prolonged period of time and had been interrogated without access to legal counsel. Because certain detainees were at risk of trial and possible death sentences before military commissions, the US had in their view failed to comply with established principles of international law (ibid).

The Commission requested the US to take the urgent measures necessary to have the legal status of the detainees determined by a competent tribunal. Without prejudging the possible application of international humanitarian law to the detainees, the Commission considered that precautionary measures were both appropriate and necessary in the circumstances, in order to ensure that the legal status of each of the detainees was clarified and that they would be afforded the legal protections commensurate with that status (IACmHR 2002). The Commission held that:

(...) no person, under the authority and control of a state, regardless of his or her circumstances, is devoid of legal protection for his or her fundamental and non-derogable human rights.

(Ibid, p. 16)

Subsequently, precautionary measures have also been issued in partially similar cases (IACmHR 2006 (detained Canadian with regard to prohibition of torture and right to integrity); IACmHR 2015a (detained Saudi in Guantánamo with regard to right to life and personal integrity due to detention conditions)).

The existing precautionary measures in Guantanamo cases have subsequently, on different occasions, been amplified, even beyond the inter-American espace juridique.

In 2003, the Commission, following an additional request for precautionary measures from Guantanamo detainees' representatives in connection with unnamed individuals alleged to have been detained in Guantanamo, but also at Bagram Air Force base in Afghanistan, the island of Diego Garcia and other similar US facilities, confirmed its earlier precautionary measures order and also requested the US for special information concerning allegations of 
ill-treatment of detainees, in particular regarding 'the location, status and treatment of individuals detained by the US in other facilities' (IACmHR 2003; further IACmHR 2004). Subsequently, the measures were amplified to take account of the alleged danger of rendition to third countries where the victim could be ill-treated (IACmHR 2005; also 2015b). On multiple occasions, the IACmHR has also called on the US to close Guantanamo (e.g. IACmHR 2012a; IACmHR 2015b).

In 2013, having been informed of US non-compliance with existing safeguards, the Commission requested information from the US government on the unnecessary and demeaning searches, the force-feeding of prisoners and the increasing segregation and isolation of prisoners, and mandated the US to extend the scope of safeguards to protect the life and integrity of the 166 remaining detainees (IACmHR 2013a).

Ameziane concerned an Algerian detainee held in 2008 at Guantanamo (IACmHR 2012b), who had been captured by the US military in Pakistan in 2002, detained at the Kandahar Airbase in Afghanistan for more than a month and later transferred to Guantanamo. While in Guantanamo, he was, among others, allegedly subjected to torture, cruel and degrading treatment and at risk of being transferred back to Algeria where he would be at risk of serious harm. The decisive element to establish the jurisdiction of the state over the apprehension of Ameziane was that the actions implied an exercise of physical power and control over him performed by US agents (ibid, paras. 31-32). The US exercised total and exclusive de facto control over this prison and the individuals detained there. As to the facts that took place in Guantanamo, the Commission indicated that the US had exercised its jurisdiction there (de jure and de facto) for more than a century (ibid, para. 33). As Guantanamo Bay fell under US jurisdiction, a precautionary measure directed to protect all prisoners detained in the Guantanamo Bay Detention Facility had been adopted by the Commission (ibid, para. 34; also: IACmHR 2002). In 2020, the IACmHR concluded that the US has violated the Declaration (IACmHR 2020, paras. 5 and 285).

Khaled El-Masri concerned the capture by Macedonian intelligence agents acting at the behest of the US Government, following which he was being held incommunicado in Macedonia for three weeks and subsequently transported (extraordinary rendition) to a prison in Afghanistan. With regard to El-Masri's apprehension, the IACmHR deferred its decision as to jurisdiction to the merits stage (IACmHR 2016, para. 25), but with regard to the alleged acts committed against Mr El-Masri during his transfer and detention at the Afghanistan 'Salt Pit' prison, the Commission held that the petitioner was under US jurisdiction due to the 'total and exclusive de facto control over the prison' in Afghanistan (IACmHR 2016, para. 25).

\section{Extraterritorial environmental obligations}

The Inter-American Court has not yet addressed extraterritorial obligations through its contentious jurisdiction. However, in its 2017 advisory opinion on the environment and human rights, the Court interpreted the concept of state obligations within Article 1(1) ACHR, in response to a request made by Colombia concerning state environmental obligations, particularly in relation to conduct outside the national territory of a state, or with effects beyond the national territory of a state (IACtHR 2017). The Court stated that the protection of human rights under the Convention includes situations beyond the territorial limits of the states, and links that concept, as the Commission has done, with the principle of universality and the jurisdiction clause (ibid, para. 78). 
The Court referred to extraterritorial obligations, emphasizing that states' human rights obligations extend to all people, even those outside of a state's borders. According to Article 1(1) ACHR, states are obligated to respect and guarantee the rights therein to all persons subject to their jurisdiction. The Court clarified that the term 'jurisdiction' in the American Convention is broader than the territory of a state, holding that a person can bring a claim if they are within the state's territory or outside the border but under a state's authority or effective control, if the state's actions caused environmental damage, and that damage resulted in a violation of a human right. The Court also indicated that states must cooperate in good faith with other states, which involves notifying, consulting and negotiating with other states whenever the state is aware that an action planned within their territory or under their control or authority may generate significant transboundary environmental harm (ibid, para. 173 and paras. 181-210).

In order to explain the scope of extraterritorial obligations within Article $1 \mathrm{ACHR}$, just like the IACmHR had done earlier, the Court also referred to the rules of interpretation for treaties, the ordinary meaning of the word jurisdiction interpreted in good faith and taking into account the travaux préparatoires as well as the context, object and purpose of the Convention (ibid, paras. 40-42) and held that the concept of jurisdiction encompasses any situation in which a state exercises effective authority or control over an individual or individuals, either within or outside its territory. Consequently, the Court emphasised that states must respect and ensure the human rights of all persons subject to their jurisdiction, even if they are not within its territory:

(...) the use of the word 'jurisdiction' in Article 1(1) of the American Convention signifies that the state obligation to respect and to ensure human rights applies to every person who is within the state's territory or who is in any way subject to its authority, responsibility or control.

(Ibid, para. 73)

(...) Accordingly, the margin of protection for the rights recognized in the American Convention was expanded insofar as the states Parties' obligations are not restricted to the geographical space corresponding to their territory, but encompass those situations where, even outside a state's territory, a person is subject to its jurisdiction. In other words, states may not only be found internationally responsible for acts or omissions attributed to them within their territory, but also for those acts or omissions committed outside their territory, but under their jurisdiction (emphasis added).

(Ibid, para. 77; also Minutes 1st session 1969, p. 145 and 147 and Minutes 2nd session 1969, pp. 156-157)

It held that the Commission had also consistently given this interpretation to the travaux préparatoires of the Convention with regard to the word 'jurisdiction' in the Convention. In sum, the Court followed the interpretation already developed by the Commission's case law (IACtHR 2017, para. 75, referring particularly to: IACmHR, 2011c, para. 91; IACmHR 1999a, paras. 15-20; IACmHR 1999c, paras. 23-25; IACmHR 1999b, para. 37).

Likewise, the Court (IACtHR 2017, para. 79) referenced cases where the Commission had recognized extraterritorial jurisdiction generally through the actions of that state's agents abroad (i.e. IACmHR 1999c; IACmHR 1993), particularly cases relating to military interventions (IACmHR 1993, paras. 14-15 and 17; IACmHR 1999b, para. 37), military operations in international airspace (IACmHR 1999c) and on the territory of another state (IACmHR 1993; 
IACmHR 2010, para. 98), as well as in military facilities outside a state's territory (IACmHR 2012b, para. 35). According to the Court:

(...) most of these situations involve military actions or actions by state security forces that indicate "control", "power" or "authority" in the execution of the extraterritorial conduct.

(IACtHR 2017, para. 80)

While the effective control test remains essential, the Court held that, with regard to crossborder damage, the exercise of jurisdiction occurs 'when the state of origin exercises effective control over the activities carried out that caused the damage and the resulting violation of human rights' in the foreign state. This basically implies that 'effective control' is no longer only something to be exercised over territory ('spatial jurisdiction') or over individual victims ('personal jurisdiction'), but also over the activities responsible for harm (ibid, para. 104(h); see Berkes 2018, para. 1). The effective control test is based on the factual, the causal nexus between conducts performed on the territory of the state of origin and a violation of rights and freedoms occurring abroad (ibid, para. 95 and paras. 101-102). A home state can eventually be held responsible for failing to exercise its obligation of 'due diligence' within its territory (Berkes 2018, para. 2).

However, the Court also emphasized that extraterritorial obligations and therefore the exercise of jurisdiction outside the territory of a state is an 'exceptional situation' that must be examined restrictively in each specific case, thereby referring to a number of cases decided by the European Court of Human Rights (i.e. Al-Skeini, Ilaşcu, Catan, Chiragov, Banković) (ibid, para. $88,104(\mathrm{~d}))$.

Specifically, in the context of environmental obligations, the Court indicated that states must ensure that their territory is not used in any way that may cause significant damage to the environment of other states or of areas outside their territorial limits. States have the obligation to prevent causing transboundary damage. Furthermore, states are obligated to adopt all necessary measures to avoid that activities - carried out on their territory or under their control - affect the rights of individuals within or outside their territory. Thus, to examine the possibility of extraterritorial exercise of jurisdiction in the context of compliance with environmental obligations, the obligations derived from the Convention must be analyzed in light of state obligations in that regard. In addition, the possible grounds for jurisdiction that arise from this systematic interpretation must be justified based on the particular circumstances of the specific case (IACtHR 2017, para. 81).

In that context, the Court held that state obligations include the obligation to take measures to prevent significant environmental harm, within and outside of their territories. The Court defined 'significant' as any harm that could result in a violation of the right to life and personal integrity. As preventative measures, states should regulate, supervise and monitor activities that could cause environmental harm, conduct environmental impact studies when there is a risk of harm, establish contingency plans and mitigate harm, if it has occurred despite the state's preventative actions. Furthermore, states have procedural obligations, which include guaranteeing access to information related to possible environmental harms, securing the right to public participation in decision-making processes about environmental impact and ensuring the right to access to justice to enforce state obligations regarding the environment (ibid, paras. 123-243).

Overall, the advisory opinion is very important because the Court broadened the scope of what extraterritorial jurisdiction implies, and it is for the first time that the Court explained its understanding of extraterritorial obligations, thus strengthening its jurisprudence in relation to the scope of states' human rights obligations. 


\section{Conclusions}

The IACmHR has established that the Declaration and the Convention have extraterritorial application, notwithstanding that the latter contains a jurisdiction clause whereas the former does not (have an explicit clause), and the IACtHR seems to have endorsed this position. The IACmHR has emphasized that the responsibility of member states is not confined to actions inside their territories, but rather extends, in addition, to circumstances occurring in the territory of another state, in international airspace or on the high seas. States in the Americas are obligated to uphold the protected rights of any person subject to their jurisdiction.

In the IAHRS, the scope of extraterritorial obligations is linked to the universality principle and the jurisdiction clause. According to the supervisory bodies, human rights are inherent to all human beings, they are not based on their nationality or location. States can be held internationally liable for deeds or omissions that were attributable to them within their own territory, but also to those perpetrated outside their territory but within the sphere in which they have jurisdiction.

This chapter examined 16 situations in practice within the IAHRS on the issue of extraterritoriality (in the ambit of country reports, contentious decisions, precautionary measures issued by the Commission and an advisory opinion issued by the Court). In most matters the facts occurred during military interventions or operations in international airspace and in the territory of another state, as well as in detention facilities outside a state's territory. In those cases, civil and political rights were violated. Only three cases before the Commission were related to violations of the American Convention, while the remainder concerned violations of the American Declaration. Once, in the ambit of an advisory opinion on the international obligations in the framework of the environment, the IACtHR has been able to deal with the issue of extraterritorial obligations. In short, most cases concerning extraterritoriality have been dealt with by the IACmHR under the Declaration.

In order to establish extraterritorial jurisdiction and ultimately responsibility, a person must be under the 'effective control or authority' of the foreign state, whereby the 'personal jurisdiction model' has been adopted as an alternative to the 'spatial jurisdiction' of control over a foreign territory. Since the extraterritorial application of human rights has been connected by the IACmHR with the recognition of the principle of universality, the threshold for the extraterritorial application of the Declaration and Convention seems to be quite low.

The Commission also stressed that, when examining the scope of the Declaration or Convention, the 'authority and control test' is based on causality. It must more specifically be ascertained whether there was a causal link between the extraterritorial conduct of a state through the actions or omissions of its agents and/or persons who have acted under its orders or acquiescence and the alleged violation of the rights and freedoms of an individual.

In its Advisory Opinion, the Court has taken things a step further, as it has broadened what constitutes extraterritorial jurisdiction by recognizing a new extraterritorial jurisdictional link based on control over domestic activities with extraterritorial effect, thereby departing from the two existing criteria to establish extraterritorial jurisdiction. While the effective control test remains essential, the Court held that, with regard to cross-border damage, the exercise of jurisdiction occurs when the state of origin exercises effective control over the activities carried out that caused the damage and the resulting violation of human rights abroad. This basically implies that 'effective control' is no longer only something to be exercised over territory ('spatial jurisdiction'), nor over individual victims ('personal jurisdiction'), but can also be something only to be exercised over the activities responsible for harm. The effective control test is based 
on the factual-causal nexus between conducts performed on the territory of the state of origin and a violation of rights and freedoms occurring abroad.

This novel interpretation of what constitutes 'effective control' seems to imply that home states, when awarding an oil or mining exploitation concession on their territory or within their waters, will in the future not be able to argue anymore that such activities are wholly beyond their 'effective control', and they can thus eventually never be held responsible for subsequent environmental degradation in case of an environmental spillover effect towards neighboring countries.

Even where the Court has clearly held that extraterritorial obligations are 'exceptional', the new jurisdictional link has opened a clear pathway to future transnational human rights claims when a state is factual-causally linked to extraterritorial situations, without it having physical control over a territory or over persons, and where a home state has the knowledge about the risk of wrongful acts and is capable of providing protection as a result of its effective control over activities within its territory. One might for example think of a home state's responsibility for the extraterritorial human rights violations by one of its (transnational) companies.

In the ambit of the earlier-mentioned situations examined by the IAHRS case law, a very broad range of rights and freedoms has been given extraterritorial application, including: the rights to life; liberty and personal security; humane treatment; preservation of health and wellbeing; equality before the law; work; a passport; property; petition; residence and movement; juridical personality; religious freedom and worship; freedom of expression; protection of honor, personal reputation and private and family life; protection of mothers and children; right to family and protection thereof; assembly; protection from arbitrary arrest; fair trial/judicial protection; due process of law; and a healthy environment.

While most alleged violations have happened within the 'inter-American espace juridique', some cases relate to actions beyond the confines of the 'Inter-American legal space', implying that the inter-American monitoring bodies, and certainly the IACmHR, have adopted an expansive view - probably also in view of the case law of the European Court of Human Rights which is regularly referred to - thereby extending the scope ratione loci of inter-American instruments and its obligations beyond the American continent, although the latter instruments were originally adopted for this specific region.

\section{References}

American Convention on Human Rights, 22 November 1969.

American Declaration on the Rights and Duties of Man, 2 May 1948.

Berkes,A. (2018) 'A New Extraterritorial Jurisdictional Link Recognised by the IACtHR', 28 March 2018, www.ejiltalk.org [accessed 8 January 2021].

Buergenthal,T. and Norris, R. (eds). (1982-1993) Human Rights:The Inter-American System, Oceana, Dobbs Ferry.

Burbano Herrera, C. and Viljoen, F. (2015) 'Danger and Fear in Prison': Protecting the Most Vulnerable Persons in Africa and the America's by Regional Human Rights Bodies through Interim Measures', NQHR 33(2), 163-193.

Burbano Herrera, C. (2011) Provisional Measures in the Case Law of the Inter-American Court of Human Rights, Antwerp, Intersentia.

Cassel, D. (2004) 'The Extraterritorial Application of Inter-American Human Rights instruments' in Coomans, F. and Kamminga, M. (eds). Extraterritorial Application of Human Rights Treaties, Intersentia.

Cerna, C. (2004) 'The Extraterritorial Application of the Human Rights Instruments of the InterAmerican System' in Coomans, F. and Kamminga, M. (eds). Extraterritorial Application of Human Rights Treaties, Intersentia. 
Cerqueira, D. (2015) 'The Attribution of Extraterritorial Liability for the Acts of Private Parties in the Inter-American System: Contributions to the Debate on Corporations and Human Rights', Aportes DPLF 20, 18-21 (available at https://dplfblog.com).

Coomans, F. and Kamminga, M. (eds). (2004) Extraterritorial Application of Human Rights Treaties, Intersentia.

Haeck, Y. Ruiz O. and Burbano-Herrera C. (eds). (2015) The Inter-American Court of Human Rights:Theory and Practice, Present and Future, Intersentia.

Inter-American Commission on Human Rights (IACmHR) (1985a) Chile Country Report. (1985b) Suriname Country Report.

(1987) Disabled Peoples International v. US, Case 9213, Admissibility Decision.

(1993) Jose Isabel Salas Galindo et al. v. US, Case 10.573, Admissibility Report 31/93.

(1996) Disabled Peoples' International v. US, Case 9213, Report to Conclude Case 3/96.

(1997) Haitian Centre for Human Rights et al. v. US, Case 10.675, Merits Report 51/96.

(1999a) Victor Saldaño v. Argentina, Inadmissibility Report 38/99.

(1999b) Coard v. US, Case 10.951, Merits Report 109/99.

(1999c) Armando Alejandre Jr et al.v. Cuba, Case 11.589, Admissibility Report 86/99.

(2002) Persons detained by the United States in Guantanamo Bay v. US, Precautionary Measures

$259 / 02$.

(2003) Persons detained by the United States in Guantanamo Bay, Precautionary measures.

(2004) Persons detained by the US in Guantanamo Bay, Precautionary measures.

(2005) Persons detained by the United States in Guantanamo Bay, Precautionary measures.

(2005) Hossein Alikhani v. US, Case 4618/02, Admissibility Report 63/05.

(2006) Omar Khadr v. US, Precautionary Measures 8/06.

(2008) Djamel Ameziane v. US, Precautionary Measures.

(2010) Franklin Guillermo Aisalla Molina (Ecuador) v. Colombia, Inter-state petition PI-02, Admis-

sibility Report 112/10.

(2011a) Resolution 2/11, Regarding the Situation of Detainees at Guantanamo Bay, United States MC 259-02.

(2011b) Danny Honorio Bastidas Meneses at al (Ecuador) v. Colombia, Admissibility Report 153/11, Petition 189/03.

(2011c) Aisalla Molina v. Ecuador, Case IP-02, Report No. 112/10.

(2012a) 10 Years After Detentions in Guantanamo Began, the IACHR Repeats its Call to Close the Detention Center, Press Release 3/12.

(2012b) Djamel Ameziane v. US, Petition P-900-08, Admissibility Report 17/12.

(2013a) Detainees in the US Military Base in Guantanamo v. United States, Extension Precautionary Measures 259/02.

(2013b) Franklin Guillermo Aisalla Molina (Ecuador) v. Colombia, Inter-state petition PI-02, Report 96/131.

(2015a) Mustafa Adam Al-Hawsawi v. US, Precautionary measure 422/14.

(2015b) Towards the closure of Guantánamo OEA/Ser.L.

(2016) Khaled El-Masri v. US, Petition 419-08, Admissibility Report 21/16.

(2018) Jose Isabel Salas Galindo v. US, Case 10.573, Merits Report 121/18.

(2020) Djamel Ameziane v. US, Petition 12.865, Merits Report 29/20.

Inter-American Court of Human Rights (IACtHR) (2017) Environment and Human Rights, Advisory Opinion OC-23/17.

Milanovic, M. (2011) Extraterritorial Application of Human Rights Treaties, Law Principles, and Policy, Oxford University Press.

Minutes of the 1st and 2nd session of Committee I on November 10,1969, in Actas y Documentos of the

Inter-American Specialized Conference on Human Rights, 1966, OAS, Washington DC.

Vienna Convention on the Law of Treaties, 22 May 1969. 